\title{
Elkarrizketak irakasleen prestakuntzarako bitarteko: irakasle-bideratzaileen jarduna ezaugarritzen
}

\author{
Interview as a tool for fostering initial teacher education development: \\ characterising teacher educators' work \\ Eneritz Garro*, Nagore Ipiña, Arantza Ozaeta
}

Humanitate eta Hezkuntza Zienzietako Fakultatea. Mondragon Unibertsitatea

\begin{abstract}
LABURPENA: Lan honen helburua da aztertzea eta ezaugarritzea unibertsitateko irakasle-bideratzaileek duten egiteko modua etorkizuneko irakasleekin euren praktikaren analisia egiteko bideoaren aurreko autokonfrontazio elkarrizketak egiten ari direnean. Lan honen corpusa osatzen dute 5 irakaslebideratzailek egindako 10 autokonfrontazio elkarrizketak. Aztertu da irakasle-bideratzaile horien rola ikasleekin egindako autokonfrontazio elkarrizketen transkribapenetan eta euren jarduna 9 kategoriatan banatu da. Horietatik bi, zehaztapenak eskatzea eta kontrobertsia sortzea, dira erabilienak. Irakasle-bideratzailearen profilaren arabera, ordea, ezberdintasunak sumatu dira jarduteko moduetan. Ondorioz, irakasle-bideratzaileekin prestakuntzan sakontzea komenigarria dela ikusi da.
\end{abstract}

GAKO-HITZAK: irakasleen hasierako prestakuntza, irakasle-bideratzailea, jardueraren analisia, autokonfrontazio elkarrizketa.

ABSTRACT: The aim of the present paper is to analyse and characterise the way in which teacher educators work with student teachers when conducting analyses of their own practice by means of selfconfrontation interviews. The corpus of this work consists of 10 self-confrontation interviews carried out by 5 teacher educators. The role of those teacher educators was analysed using the transcriptions of the interviews and 9 categories were identified. Two categories were found to be the most common: demanding specifications and creating controversy. Differences were also found as regards teacher educators' profile. As a result, in-depth training for teacher educators has been considered as needed.

KEYWORDS: initial teacher education, teacher educators, analysis of the activity, self-confrontation interviews.

\footnotetext{
* Harremanetan jartzeko / Corresponding author: Eneritz Garro. Mondragon Unibertsitatea. Hizkuntzaren eta Literaturaren Didaktika. Humanitate eta Hezkuntza Zienzietako Fakultatea. Dorleta auzoa, z/g. E-20540 Eskoriatza - egarro@mondragon. edu - https://orcid.org/0000-0002-6148-8383
}

Nola aipatu / How to cite: Garro, Eneritz; Ipiña, Nagore; Ozaeta, Arantza. (2018). «Elkarrizketak irakasleen prestakuntzarako bitarteko: irakasle-bideratzaileen jarduna ezaugarritzen»; Tantak, 30(2), 99-116. (https://doi.org/10.1387/tantak.19462).

Jasotze-data: 2018/04/25; Onartze-data: 2018/07/17

ISSN 0214-9753 - elSSN 2444-3581 / (c) 2018 UPV/EHU

(c) Obra hau Creative Commons Atribución 4.0 Internacional-en 


\section{SARRERA}

Eskola aldatzen ari da eta baita eskolak eskatzen duen irakasle profila ere. Erronka berriei aurre egiteko gai diren profesionalak behar ditu eskolak, konplexutasuna eta ezjakintasuna kudeatzeko gai izango direnak, beren ardurapean izango dituzten ikasleetako bakoitzaren garapena sustatu, bideratu eta laguntzeko bitartekoak dituztenak. Eta ondorioz, aldatu beharra du unibertsitateak irakasle profil berri horiei eman beharreko prestakuntzak ere. Irakasleen hasierako prestakuntza ez da oinarritu behar soilik kanpotik eraikitako ezagutzan eta horren transmisioan, prestakuntza prozesuan leku esanguratsua izan beharko luke etorkizuneko irakasleek eurek, praktikatik abiatuta, eraikitzen duten jakintzak (Alsina, 2013). Etorkizuneko irakasleek hasierako prestakuntzan bertan bizi behar dituzte gela barruko, ikastetxeko zein hezkuntza komunitateko konplexutasuna, ezjakintasuna eta tentsioa, betiere berdinez zein profesionalez babesturiko testuinguru batean. Hasiera-hasieratik sustatu behar da gogoeta askotariko egoerei buruz eta beren buruari buruz, aztertu behar dituzte beren irakas-jardunak eta jabetu behar dira horien ondorioez (Perez Gómez, 2010).

Testuinguru honetan gainditu nahi dugu irakasleen prestakuntzarako ikuspegi aplikazionista, zeinean iturri nagusi gisa hartzen diren, batetik, heziketa politikaren proposamenak eta, bestetik, erreferentziazko zientzietako ezagutzak (pedagogiak, psikologia, hizkuntzalaritza...) (Alonso, Azpeitia, Iriondo \& Zulaika, 2017; Plazaola, Elosegi, Ruiz Bikandi, Arregi \& Badiola, 2013). Schön-en (1987) ondotik hainbat ikerlarik proposatu dute gogoetan oinarritutako irakasleen prestakuntzako ereduak direla irakasleen gaitasun profesionalak modu esanguratsuan garatzeko edo profesionalizazioaren bidean laguntzeko eraginkorrenak (Beauchamp, 2015; Dewey, 1993; Grant \& Zeichner, 1984; Hatton \& Smith, 1995; Korthagen, Kessels, Koster, Lagerwerf \& Wubbels, 2001; Tardif, Borges \& Malo, 2012; Tripp \& Rich, 2012) eta ikuspegi teoriko desberdinetatik bultzatu da irakasleen prestakuntzan praktikaren analisia (Dolz \& Leutenegger, 2015). Praktika da, beraz, ikaskuntza profesionalerako abiapuntua. Praktika horren analisirako hainbat metodologia eta teknika proposatu dituzte ikerlari zein prestatzaileek: egunkariak (Zabalza, 2004), berdinen arteko behaketak (Peake, 2006; Burrows, 2008), portafolioa (Pozo \& García, 2006), gogoeta partekatuak (Mauri, Clará, Colomina \& Onrubia, 2017) edota autokonfrontazio elkarrizketak (Clot, 1999; Thereau, 1992). Irakasle hasiberrien prestakuntzan, gogoeta prozesua gidatua izan behar dela azpimarratzen du Russell-ek (2005); izan ere, hasiberriek ez dute beti ulertzen beren praktikaren inguruan hausnartzeak zer onurak dakartzan (Ward \& McCotter, 2004). Garrantzitsua da ulertzea zertan/nola eragiten duten etorkizuneko irakasleen praktika gogoetatsuetan eskainitako laguntza egiturek (Gelfuso \& Dennis, 2014). 


\subsection{Autokonfrontazioa etorkizuneko irakasleen prestakuntzarako bitartekari}

Irakasleak irakaskuntzarako prestatzeak esan nahi du, besteak beste, prestatzea gelan jarduerak egiteko, jarduera hezitzaileak. Horregatik hartzen dugu aintzat prestakuntzako orientabide gisa lanean garatutako jardueraren analisia (Bronckart eta beste, 2004; Durand, 2008). Etorkizuneko irakasleen prestakuntzan, ohiko praktika bihurtzen ari da norberaren burua jardunean grabatu eta horren gaineko gogoeta egitea, bereziki practicumaren garaian. Autore batzuek diotenez (Ozaeta, 2013; Russell, 2005), etorkizuneko irakasleek beren burua grabatzeak eragiten du lanaren eta lanbidearen inguruko gogoeta aberatsagoak gauzatzea. Gogoeta horiek batzuetan idatzizkoak dira (egunkari, portafolio) eta beste batzuetan, aldiz, bideratzaile baten laguntzaz egiten diren elkarrizketak. Askotariko elkarrizketak egin daitezke eta horietako bat autokonfrontazio elkarrizketa delakoa da, zeina profesionalizazioaren azeleragailutzat har daitekeen, bereziki etorkizuneko irakasleen prestakuntzan (Ria, Serres \& Leblanc, 2009).

Autokonfrontazioa gaur egun hainbat hurbilbidetan (lanaren psikologia, aktibitatearen analisia, aktibitatearen klinika, antropologia kognitiboa, besteak beste) erabiltzen den formakuntza eta ikerketa teknika da. Teknika horren muina subjektua bere jarduerari edo lanari buruzko irudien aurrean jartzea da eta prestatzaile-ikerlariak eskatzen dio bere jarduera berbara ekartzeko. Prestatzaile-ikerlariak laguntzen dio aktoreari (irakasleari) deskribatzen zer egiten zuen, pentsatzen zuen, kontuan hartzen zuen eta sentitzen zuen jardueraren unean (Ozaeta, 2013). Autokonfrontazio elkarrizketaren ezaugarrietako bat da elkarrekintzan eta egile-prestatzailearen arteko elkarrizketan oinarritzen dela (Clot \& Faïta, 2000). Elkarrizketa gauzatzen da hiru erpin kontuan hartuta: prestatuko den subjektua, prestatzailea eta bideoa bera, eta dialogismorako hitzarmena da beharrezko baldintza. Autokonfrontazioa egiteko hiru baldintza bete behar dira (Theureau \& Jeffroy, 1994); lehenik eta behin, hizkuntza eta kultura baldintzek ziurtatu behar dute egileak eta prestatzaile-ikerlariak partekatzen dutela hizkuntza eta kultura gutxienekoa; bigarrenik, egilearen eta prestatzaile-ikerlariaren arteko konfiantza harremana egon behar da; eta hirugarrenik, galdeketarako baldintza materialak bermatu behar dira.

Autokonfrontazio elkarrizketak hainbat helburu ditu irakasle hasiberrien praktikaren azterketan: bilatzen da aktoreak bere buruarekiko harridura edo sorpresa rol bat hartzea, bere jarduera gidatzen duten aukeren justifikazio eta analisia egitea, eta, areago, horiek zalantzan jartzea (Ozaeta, 2013), bai eta ikusten duen horretatik abiatuta beste aukera posible batzuk, bere jarduera hobe ditzaketenak, arakatzea ere. Prozesu horretan beraz, irakasle hasiberriak ez ezik, irakasle-bideratzaileak edo prestatzaileak ere badu ardura garrantzitsua (Bikuña, Sagasta \& Ipiña, 2017; van Es, Tunney, 
Goldsmith \& Seago, 2014) eta, ondorioz, bere rola eta jarduteko modua aztertzea ezinbestekoa da (Beauchamp, 2015).

\subsection{Bideratzaileen garrantzia}

Hainbat ikerketak azpimarratzen dute autokonfrontazio elkarrizketetan bideratzailearen rolak eta jarduteko moduak duen garrantzia (Beauchamp, 2015; Gaudin \& Chaliès, 2012; Gaudin \& Flandin, 2014). Borer eta Muller-ek (2016) galdetzen dute ea nahikoa den bideratzailea egote hutsa autokonfrontazioaren funtzionamendu egokia bermatzeko, edota bideratzaileak objektu ezberdinak proposa ditzakeen une jakin batzuetan. van Es eta bestek (2014) ere aipatzen dute bideratzailearen lana zentrala dela esperientzietatik ikaskuntza posible izan dadin. Horretarako ordea, bideratzailearen rola eta egiteko moduak hobeto ezagutu behar direla aipatzen dute. Autore horien esanetan gogoeta e(ra)giteko estrategia desberdinak erabiltzen dira formakuntza-eredu desberdinetan; batzuetan prestatzaileek eurek aukeratzen dute bideo pasartea, pasarte kritikoak ere baliatzen dira, edota egileak berak hautatzen du aztertuko dena. Prestatzaileek taldeko arauak adosten eta betearazten dituzte talde-gogoeta den kasuetan; teoriarekin loturak bilatzen dituzte edota esandakoak laburtzen eta borobiltzen dituzte; jarduera partikularrak eta ideia orokorrak lotzen dituzte... Hala ere, azpimarratzen dute kasu guztietan ikus daitekeela bideratzaileek zenbait erabaki hartzen dituztela aurretiaz eta estrategia zehatzak erabiltzen dituztela bideoaren erabilera irakasleen ikaskuntza prozesuan esanguratsua izan dadin.

Halaber, kontuan hartu beharreko beste alderdi bat bada, autokonfrontazioan askotan bideratzaileak bi rol hartu ohi ditu bere gain, aldi berean da batetik prestatzailea eta bestetik ikerlaria (Azpeitia, Alonso \& Garro, 2013; Plazaola eta beste, 2015) eta horrek izan dezake eragina autokonfrontazio elkarrizketaren garapenean. Bukatzeko, Beauchamp-ek (2015) azpimarratzen du bideratzailearen formakuntza beharra; hau da, beharrezkoa dela rol hori hartu behar dutenek irakasleen praktika gogoetatsua nola sustatuko duten ikastea, hain zuzen, prestatzen den subjektua kalitatezko gogoetak egitera bideratzeko. Horretarako, gomendatzen du hausnarketa prozesua esplizitatu eta jarraitutako pausoak berdinkideekin partekatzea. Bideratzaileen formakuntzari dagokionez ere, beste hainbat lanek (Bikuña, Sagasta \& Ipiña, 2017; Ipiña, Bikuña \& Sagasta, 2018) azpimarratzen dute bideratzaileek sustatzen dituzten galdera moten inguruko prestakuntza beharra. Izan ere, ildo horretako lanek erakutsi dute bideratzaileek egiten dituzten galderen ezaugarriek (irekiak edo itxiak, galdera motak, galderen funtzioak...) badutela eragina etorkizuneko irakasleen praktika gogoetatsuan. 


\section{METODOLOGIA}

Ikerketa lan honen helburua da aztertzea jardueraren analisian oinarrituriko irakasleen hasierako prestakuntza prozesu baten baitan bideoaren aurreko autokonfrontazio elkarrizketetan irakasle-bideratzaileek nola jarduten duten. Jakin nahi dugu: a) irakasle-bideratzaileen esku-hartzea nolakoa den irakasle hasiberriek beren irakats-jarduera aztertzen duten bitartean (aukerarik ematen ote dieten beren praktikaren gainean hobekuntzak proposatzeko, etorkizuneko irakasleei bururatzen ote zaien gogoeta gai berririk, zein posiziotan kokatzen den irakaslearekiko, ba ote dagoen etorkizuneko irakaslearekin batera objektu komun bat eraikitzeko estrategiarik...); b) Fakultate bereko irakasle-bideratzaileen artean zein antzekotasun eta desberdintasun dauden jarduera hori gauzatzerakoan.

Zehaztutako helburuari erantzuteko ikerketa kualitatiboa erabili da. Ikerketa eredu honek xede du pertsonen jokaera gidatzen duen errealitatea kontzeptualizatzea. Kontzeptualizazio horren oinarria izango da testuinguru - espazio eta denbora - jakin bat partekatzen dutenen ezagutza, jarrera eta balioak partekatzea (Newby, 2010). Parte hartzaileen esperientzia eta sentimenduak azpimarratzen dira ikerketa kualitatiboan eta, ondorioz, prozesuaren izaera esploratzaileari ematen zaio garrantzia (Bogdan \& Biklen, 1992; Dörnyei, 2001).

\subsection{Parte-hartzaileak}

Ikerketa lan hau kokatzen da Mondragon Unibertsitateko Haur Hezkuntza eta Lehen Hezkuntza Graduetan eta lan honetan parte hartu dute 5 irakasle-bideratzailek (4 emakume eta gizonezko bat): Haur Hezkuntza Graduko bik (ibilbide orokorra) eta Lehen Hezkuntza Graduko hiruk (1 ibilbide orokorrekoa, 1 Heziketa Fisikoko ibilbidekoa eta 1 Atzerriko Hizkuntza ibilbidekoa). Irakasle-bideratzaile bakoitzak ikasturte bakoitzean graduotako 4. mailako 20-30 etorkizuneko irakasleri egin ohi dio autokonfrontazio elkarrizketa prestakuntza prozesu baten testuinguruan.

Autokonfrontazio horiek egiten dira «Ikerketa Eskolan» deritzon materiaren baitan. Materiak 6 ECTS ditu; 60 ordu presentzial eta 90 ordu ezpresentzial. Hamaika astetako materia bat da, zeina bi ataletan banatzen den eta zuzenean elikatzen den Practicumetik [ikus Irudia 1.]. Hau da, materiaren lehenengo atala lantzen da Practicumaren lehenengo egonaldiaren aurretik eta bigarrena berriz, ostean. Era berean, Practicumaren bigarren egonaldia eta Gradu Bukaerako Lana (GBL) elikatzen ditu materiak. «Ikerketa Eskolan» materiaren helburu nagusia da praktika gogoetatsuaren ikuspegitik etorkizuneko irakasleei beren praktikaren inguruan hausnartzeko tresnak eskaintzea. 


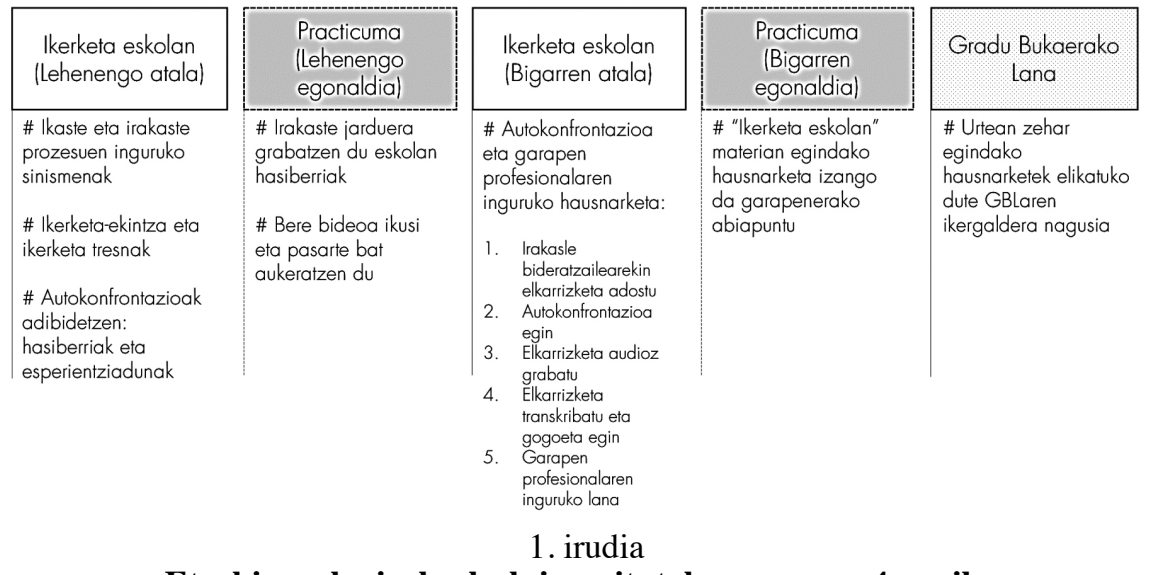

Etorkizuneko irakasleek jarraitutako prozesua 4. mailan

\subsection{Datuak jasotzea eta prozedura}

Artikulu honetan aztergai izan ditugu irakasle-bideratzaileen autokonfrontazio-elkarrizketa bana; guztira, beraz, bost elkarrizketa. Corpusa etorkizuneko irakasleek egindako autokonfrontazio elkarrizketen grabaketek eta transkripzioek osatzen dute. Elkarrizketek 39 minutuko iraupena dute bataz beste eta arestian azaldu den «Ikerketa Eskolan» materiaren bigarren atalean kokatzen dira [ikus 1. irudia]. Hau da, autokonfrontazio elkarrizketak egiteko prozedura honako hau da: irakasle hasiberriak bere ikaste jarduera grabatzen du Practicumeko lehenengo egonaldian, bideoa ikusten du eta pasarte bat aukeratzen du. «Ikerketa eskolan» materiaren bigarren atalean etorkizuneko irakasleak irakasle-bideratzailearekin adosten du elkarrizketa, eta autokonfrontazioa egiten du. Elkarrizketa audioz grabatzen da eta ondoren, etorkizuneko irakasleak transkribatu eta transkripzioaren gainean gogoeta egiten du. Biak, transkripzioa eta gogoeta, materiaren azken lanean txertatzen ditu irakasle hasiberriak. Transkripzio horietatik abiatuz honako pauso hauek eman dituzte ikerlariek autokonfrontazio elkarrizketan irakasle-bideratzaileek duten esku-hartzea aztertzeko:

- Hiru ikerlariek corpusa interakzio unitatetan banatu dute. Interakzio unitateak definitu dira gai baten inguruko galdera-erantzunen atala bezala (Ward \& McCotter, 2004). Unitate berri baten hasiera eztabaida-gai berri baten hasierarekin identifikatu da, zeinak aurreko gaiarekin lotura zuzenik ez duen.

- Irakasle-bideratzaileen berbaldiak identifikatu dira autokonfrontazio elkarrizketen interakzio-unitate bakoitzean. 
- Ikerlarietariko bik autokonfrontazioetako bat aztertu dute nork bere aldetik eta hamabi kategoria proposatu ditu bakoitzak. Ikerlariek aurkitu dituzte hamar kategoria berdin eta bi desberdin. Guztira beraz, 14 kategoria identifikatu dira.

- Corpuseko autokonfrontazio elkarrizketa bera aztertu dute hiru ikerlariek identifikatutako 14 kategoriak kontuan hartuta. Azterketaren adostasun maila hurrengoa izan da: \% 50ean hiru ikerlariak ados daude kategorizazioan, \% 39an bi ikerlari ados daude, \% 11n ikerlariak ez dira bat etorri. Bateratze eta eztabaida saio baten ondoren azterketarako 9 kategoria adostu dituzte. Hauek dira azterketarako adostu diren kategoriak: [01] kontsigna ematea, [02] zehaztapenak eskatzea, [03] kontrobertsia sortzea, [04] teoriarekin loturak egitea, [05] beste aukera batzuk proiektatzea, [06] hitzak berrartzea, birformulatzea edota osatzea, [07] babes emozionala ematea, [08] autokonfrontazioaz galdetzea eta [09] laburbiltzea eta etorkizuna proiektatzea.

- Beste 4 autokonfrontazioak aztertu dituzte eta bikoteka egin dute kontrastea, ia adostasun osoz (\%93) kategorizatu dute corpusa. Ikerlariak bat etorri ez diren kasuetan, eztabaida zabaldu da adostasunera heldu arte.

- Amaitzeko, kategorietako adibideak testuinguruan aztertu dituzte modu dinamikoan, bereziki disposizioari erreparatuz.

\section{ANALISIA ETA EMAITZAK}

Arestian aurreratu dugun bezala, irakasle-bideratzaileen esku-hartzea 9 kategoriaren bidez ezaugarritu da:

1. taula

Irakasle-bideratzaileen esku-hartzearen 9 kategorien deskribapena

\begin{tabular}{c|l}
\hline Kategoria & \multicolumn{1}{c}{ Deskribapena } \\
\hline $\begin{array}{c}{[01]} \\
\text { kontsigna ematea }\end{array}$ & $\begin{array}{l}\text { irakasle hasiberriari adierazten zaio zer den be- } \\
\text { rarengandik espero dena autokonfrontazio elka- } \\
\text { rrizketan zehar }\end{array}$ \\
\hline $\begin{array}{c}{[02]} \\
\text { zehaztapenak eskatzea }\end{array}$ & $\begin{array}{l}\text { irakasle hasiberriari bere jarduera hobeto uler- } \\
\text { tzeko datuak eskatzen zaizkio }\end{array}$ \\
\hline 03$]$ & $\begin{array}{l}\text { irakasle hasiberriari bere jarduerarekiko ikuspegi } \\
\text { desberdinak azaleratzeko baieztapenak edota } \\
\text { galderak proposatzen zaizkio, aurrez prestaturik } \\
\text { izan dezakeen diskurtsoa aldaraziz }\end{array}$ \\
\hline
\end{tabular}


Eneritz Garro, Nagore Ipiña, Arantza Ozaeta

\begin{tabular}{c|l}
\hline Kategoria & \multicolumn{1}{c}{ Deskribapena } \\
\hline $\begin{array}{c}\text { [04] } \\
\text { teoriarekin loturak egitea }\end{array}$ & $\begin{array}{l}\text { bideoan ikusten den jardueraren eta teoriaren lo- } \\
\text { turak egiten ditu edota eginarazten ditu irakasle- } \\
\text { prestatzaileak }\end{array}$ \\
\hline $\begin{array}{c}\text { [05] } \\
\text { beste aukera batzuk } \\
\text { proiektatzea }\end{array}$ & $\begin{array}{l}\text { bideoan ikusten den jardueratik abiatuta beste } \\
\text { jarduera posible batzuk edota hobekuntza propo- } \\
\text { samenak egitea xede du irakasle prestatzaileak }\end{array}$ \\
\hline $\begin{array}{c}\text { [06] } \\
\text { hitzak berrartzea, } \\
\text { birformulatzea edota osatzea }\end{array}$ & $\begin{array}{l}\text { irakasle hasiberriak esandakoa errepikatzen, za- } \\
\text { baltzen edota zehazten du irakasle prestatzaileak } \\
\text { helburu desberdinekin }\end{array}$ \\
\hline $\begin{array}{c}\text { [07] } \\
\text { babes emozionala ematea }\end{array}$ & $\begin{array}{l}\text { irakasle hasiberria laguntzen du, animoak ema- } \\
\text { naz edota (auto)kritikak leunduz }\end{array}$ \\
\hline $\begin{array}{c}\text { 08] } \\
\text { autokonfrontazioaz galdetzea }\end{array}$ & $\begin{array}{l}\text { autokonfrontazioa egitearen esperientziaz galde- } \\
\text { tzen du }\end{array}$ \\
\hline $\begin{array}{c}\text { [09] } \\
\text { laburbiltzea eta etorkizuna } \\
\text { proiektatzea }\end{array}$ & $\begin{array}{l}\text { autokonfrontazioan zehar esandakoen sintesia } \\
\text { egiten du eta aurrera begirako pausoak aurrei- } \\
\text { kusten laguntzen du }\end{array}$ \\
\hline
\end{tabular}

Identifikatutako kategoria bakoitzaren emaitzak eta adibideak aurkezten dira hurrengo azpiataletan.

\subsection{Kontsigna ematea}

Adibidea 1.

Irakasle-bideratzailea 1 eta irakasle hasiberri baten arteko elkarrizketa zatia

Irakasle-bideratzailea 1: bueno ariketa honen helburua badakizu da ikustea pixka bat zu gela barruan, bai? Eta eh ba saiatzea berriz bizitzen bizi izan zenduna eta ulertzen apur bat ba hor ikusten dan horretan ba zer ari dan gertatzen, bale?

Irakasle hasiberria 1: bale.

Irakasle-bideratzailea 1: orduen da ba zure jardueraren azterketa. Zuk erabakiko dozu ze ikusiko dogun, nun gelditu, bale? Zeri erreparatzen diozun, kokatu apurtxo bat, testuinguratu .

Bost irakasle-bideratzailetik bik (irakasle-bideratzailea 1 eta irakaslebideratzailea 2) modu antzekoan eman diote kontsigna irakasle hasiberriari 
eta formula nahiko formala erabili dute horretarako (adibidean ikusgai), beste hirurek ez dute horrelako formularik edo antzekorik erabili. Adibidean ikus daiteke irakasle-bideratzaileak irakasle hasiberria kokatzen duela autokonfrontazio elkarrizketan, adieraziz helburua ez dela egiten duena baloratzea edota ebaluatzea, baizik eta gelan egindako jardueraren inguruan eta bizitako esperientziaren inguruko hausnarketa egitea.

Berdin jarduten duten bi irakasle-bideratzaileak ikerketa talde berekoak dira, beraz, pentsa daiteke autokonfrontazioaren inguruko egiteko moduak elkarrekin bateratuak dituztela edota marko teoriko baten moldeei erantzuten dietela (Plazaola \& Ozaeta, 2014). Aztertutako transkripzioetan kontsigna modu formalean egin ez duten hiru irakasle-bideratzaileen kasuan arrazoi ezberdinak egon daitezke tartean: izan daiteke kontsigna hori ez eman izana formalki edota etorkizuneko irakasleek elkarrizketa hasierak eta amaierak ez transkribatzea edo grabagailua kontsigna eman ondoren martxan jartzea besteak beste.

\subsection{Zehaztapenak eskatzea}

Adibidea 2.

Irakasle-bideratzailea 3 eta irakasle hasiberri baten arteko elkarrizketa zatia

Irakasle hasiberria 2: saiatu nitzan rotazioa nundikan noa izango zan esplikatzen. Leno esplikatu nien baino birgogoratzen. Ta bein bakoitza bere lekun jarrita errexo bisualizatzeko. Baino karo nola ya material guztia emana nekan pues zarata ikustea umek nola altutu zuten.

Irakasle-bideratzailea 3: Zein zan taldekako lan honen helburua?

Irakasle-bideratzaile guztiek erabiltzen duten estrategia da zehaztapenak eskatzea eta baita maiztasun handiena duen kategoria da - nahiz eta zehatz-mehatz ez ditugun maiztasunak neurtu, joera esanguratsua dela esan dezakegu - . Emaitzek erakusten dute mota desberdinetako zehaztapenak eskatzen dituztela irakasle-bideratzaileek: jardunaren momentuko sentimenduak ulertzera bideratuak (tentsioak, ardurak, zalantzak, sinesmenak...), jardueraren inguruko informazio gehigarria lortzera bideratuak edota egilearen helburu zein arrazoiak ulertzera bideratuak. Esan beharra dago ordea, ikerketa talde berekoak diren bi irakasle-bideratzailek erabiltzen dutela gehien estrategia hau.

Irakasle hasiberriek egin beharreko ariketa konplexua da, jardueraren momentura itzuli behar baitute. Espero da elkarrizketa eta irakasle-bideratzailearen galderek bideoan elkarrekin ikusten duten jarduera hobeto ulertzen laguntzea. Jarrera beraz, jarduera ulertzearekin lotuta dago (ad. zein zan taldeko lan honen helburua?) eta oro har, ez dira etorkizuneko irakasleak egin duen hori ebaluatzeko galderak. 


\subsection{Kontrobertsia sortzea}

Adibidea 3.

Irakasle-bideratzailea 1 eta irakasle hasiberri baten arteko

elkarrizketa zatia

Irakasle hasiberria 1: bai bai egixa da. Ba ikusi horrena enaz konturatu, baina eske ume hori orduen ikusezina izan da niretako.

Irakasle-bideratzailea 1: zentratzeko daukazun moduagatik.

Irakasle hasiberria 1: bai.

Irakasle-bideratzailea 1: karo arreta selektibua da. Arreta da selektibua.

Irakasle hasiberria 1: bai bai eske jarten dot arreta hortan eta beste dana da.... eta hori zer?

Irakasle-bideratzailea 1: arreta da selektibua. Zuk ikusten dozu hau, baina ez dozu ikusten ingurua.

Irakasle hasiberria 1: hori da, hori da...

Irakasle-bideratzaileek kontrobertsia sortzen dutenean irakasle hasiberriek batzuetan proposamen hori hartu egiten dute eta garatu, aztertu eta xehetu (ad. Irakaslea 1 : klaro arreta selektiboa da. Arreta da selektiboa I Ikaslea 1: bai bai eske jarten dut arreta hortan eta beste dena da... eta hori zer?); beste batzuetan, aldiz, ez dute prestatzaileak proposatutako gai aldaketa hori onartzen eta ez dute gai berri horretatik tiraka ideiarik garatzen. Azterketa honen emaitzetan ikusi dugu kategoria honek forma desberdinak izan ditzakeela: galdera ireki forma, baieztapen forma...

Badu, ordea, beste funtzio bat ere. Etorkizuneko irakasleek bideoa etxean ikusten dutenez, askotan prestatutakoa azalpen hutsez emateko joera erakusten dute autokonfrontazio saioetan. Halakoetan, egindako lanaren justifikazioa nagusitzen da, eta diskurtso egituratu baten forman azaltzen da (Plazaola \& Ozaeta, 2014). Irakasle-bideratzailearen rola izan ohi da kontrobertsiaren bidez aurrez prestatutako diskurtso arrazional hori etetea eta irakasle hasiberrien aldetik diskurtso berri bat sortzen saiatzea, forma diskurtsibo desegituratuago bat bilatuz, jardueraren inpresio, aztarna eta hazi formatiboak bilatzen dituena.

\subsection{Teoriarekin loturak egitea}

Adibidea 4.

Irakasle-bideratzailea 1 eta irakasle hasiberri baten arteko elkarrizketa zatia

Irakasle hasiberria 1: bai bai eske jarten dot arreta hortan eta beste dana da.... eta hori zer? 
Irakasle-bideratzailea 1: arreta da selektibua. Zuk ikusten dozu hau, baina ez dozu ikusten ingurua.

Irakasle hasiberria 1: hori da...

Irakasle-bideratzailea 1: begirada periferikoa

Irakasle hasiberria 1: pfff hor in bida lanketa bat...

Teoriari dagokionez gure analisietan ikusi dugu apenas dagoela «teoria» $-\mathrm{T}$ handiz - adierazten duten interbentziorik, ez da ia aipatzen autorerik, edo epistemiarik. Irakasle hasiberriek teoriari erreferentziak egiteko dituzten zailtasunak aztertu dituzte hainbat egilek (Gaudin \& Chaliès, 2012) eta gure kasuan ere, agerikoa da teoria falta. Emaitzetan, teoria hori gauzatzen da soilik irakasle-bideratzaileek beren ikuspegia ekartzean (Irakasle-bideratzailea 1: arreta da selektibua. Zuk ikusten dozu hau, baina ez dozu ikusten ingurual Irakasle hasiberria 1: hori da... Irakasle-bideratzailea 1: begirada periferikoa), practicumean bizitako esperientzietatik eratorritako baieztapenetan edota irakasle-bideratzaileak ikasketa planari erreferentzia egitean.

Teoriaren kategoria azpian identifikatutako aipu askok lotura dute Mondragon Unibertsitateko hezkuntza proiektuarekin (talde lanaren garrantzia eta eragina adibidez -ikus Adibidea 5-). Askotan gainera, ordena aldetik, aurreko bi kategorien ([02] zehaztapenak eskatu edo [03] kontrobertsia sortu) hurrengo urrats moduan agertzen da. Estrategia hau da aztertutako corpusean gutxien ageri den estrategia. Erabili da bereziki Heziketa Fisikoa ibilbideko autokonfrontazio elkarrizketan.

\subsection{Beste aukera batzuk proiektatzea}

Adibidea 5.

Irakasle-bideratzailea 3 eta irakasle hasiberri baten arteko elkarrizketa zatia

Irakasle hasiberria 3: hemen, taldekatzei gela hontan eztiyet garrantziyik ematen, ze eztao, adibidez ... ta leno gaxki esan det, hau ezta $C$, da D. Gela hontan eztao beti bat bakarrik geatzea o hau eztue kontutan hartzen; ordun, taldekatzekin batzutan iteitut 1-2-3, 1-2-3, 1-1-2, bata batakin, biyak biyakin hiruak hiruakin; bestetan filan jarri ta 1-2-3 zuek bat, 1-2-3, zuek bestia... hola, eztiyot garrantziya ematen. Bai ikustetela hobetzeko baloyak banatzia, taldek itia... hori dana, igual aurrena, kasu hontan, azaldu ze in ber deten eta gero talden in eta materiala banatu. Beste... zuk esantzenian bezela «error de principiante» ta denai gertatze zayen hori.

Irakasle-bideratzailea 3: bai. Edo taldeak egin daitezke...

Irakasle hasiberria 3: ikasleei arbelean euren izenak apuntatzeko aukera emanez adibidez. 
Autokonfrontazio elkarrizketaren itxieran ohikoa da egindako jardueraren inguruan etorkizunerako aukera desberdinak aipatzea edota egindako lanaren aldaerak proposatzea (Clot \& Faïta, 2000). Hortik eratortzen da, askotan, elkarrizketa hauen balio prestatzailea.

Aztertutako lanetan ikusi dugu batzuetan irakasle-bideratzaileak berak egiten duela proposamena eta beste batzuetan hasiberriari eskatzen diola etorkizunera begirako beste proposamen batzuk egiteko (Irakasle-bideratzailea 3: bai. Edo taldeak egin daitezke... Irakasle hasiberria 3: ikasleei arbelean euren izenak apuntatzeko aukera emanez adibidez). Halaber, espero bezala, ikusi dugu autokonfrontazioaren elkarrizketa amaieran agertzen den kategoria dela hau eta irakasle-bideratzaile guztiek egiten dutela.

\subsection{Irakasle hasiberriaren hitzak berrartzea, birformulatzea edota osatzea}

Adibidea 6.

Irakasle-bideratzailea 4 eta irakasle hasiberri baten arteko

elkarrizketa zatia

Irakasle hasiberria 4: Ta or yo noseke.

Irakasle-bideratzailea 4: Bakoitzak berea.

Irakasle hasiberria 4: Karo ebai zazpi urte dazkate ordun zaila da ez. badaude ohituta taldian lan itea kontun hartuta adin ortan oaindik eta ni ni ni gehio dakatela zaila da. Eztakit.

Helburu desberdinak izan ditzake irakasle hasiberriaren hitzak berrartzeak, beste modu batez adierazteak edota osatzeak. Lan honetan ikusi dugu batzuetan elkarrizketa bidezkoa dela estrategia hau (jarraitu, jarraitu esateko), beste batzuetan ulermena ziurtatzeko egiten dela, hainbatetan irakasle hasiberriari bere diskurtsoa osatzen laguntzeko egiten dela (Irakasle hasiberria 4: Ta or yo noseke./ Irakasle-bideratzailea 4: Bakoitzak berea.)... Irakasle-bideratzaile guztiek erabiltzen dute estrategia hau baina ohikoa da beste kategoria batzuekin batera agertzea, batez ere bi kategoria hauekin: [02] zehaztapenak eskatu edo [07] babes emozionala eman. 


\subsection{Babes emozionala ematea}

Adibidea 7.

Irakasle-bideratzailea 5 eta irakasle hasiberri baten arteko elkarrizketa zatia

Irakasle hasiberria 5: I don't know, the second day that I told that so... it's very... Some of them, they know, but others don't know so, maybe later, I can interact or ask.

Irakasle-bideratzailea 5: Yes, definitely. Very interesting.

Irakasle hasiberria 5: I think I have to improve those aspects. But I think that the experience will help me a lot.

Irakasle-bideratzailea 5: Definitely. It's not easy because... many things that we need to bear in mind, isn't it?

Oso modu desberdinetan ematen da babesa, baina autokonfrontazio guztietan agertzen den kategoria da, lanaren irudiak aztertzeak egilearentzat dakarren arrisku egoera saihesteko-edo. Konfiantzazko giro bat sortzearekin lotuta egon daiteke, baita etorkizuneko irakasleak saioari inplizituki har diezaiokeen ebaluazio kutsua leuntzeko. Estrategia hau bereziki Atzerriko Hizkuntzako ibilbideko irakasle-bideratzaileak erabiltzen du eta agian lotua dago ikasleen hirugarren hizkuntzan ari izatearekin, eta baliteke beharrezkoagoa izatea enpatia erakustea eta babes emozionalaren formak erabiltzea hori erakusteko (ad. Irakasle-bideratzailea 5: Yes, definitely. Very interesting).

\subsection{Autokonfrontazioaz galdetzea}

Adibidea 8

Irakasle-bideratzailea 1 eta irakasle hasiberri baten arteko elkarrizketa zatia

Irakasle-bideratzailea 1: eta bukatzeko. Horrelako jarduera bat, jun gela, grabatu, zeuk ikusi. Ikusiko zenun behin edo behin etxian?

Irakasle hasiberria 1: Ba behin bakarrik ikusiet.

Irakasle-bideratzailea 1: Ta oain nerekin ikusteak ze balio du? O ze balio ematen diozu? Baliagarria in zaizu?

Irakasle hasiberria 1: Bai, ze iwal etxian ikusi nun baino jarri nun txipa etxian aztertzeko baino geio ze eakutxi ta ya behin emen jarrita gehio sartu naiz gehio sartzeko aukera izan det ta bizitzeko ta ikusteko jo ba gauza batzuk adibidez ikasliak bakarka lanian zeudela oi han enitzan kontuatu ta etxian ikusi nunian de ez ordun bai ematen dizu aukera ikusteko gauzak benetan momentun ikusi ezin dianak. Ta re bai ikusteko ze in dezun ondo ta zer hobetu beharko zenuken. 
Jarduera ezohikoa izanik, irakasle hasiberriei galdetzen zaie autokonfrontazio elkarrizketa egitearen esperientziaz eta, era berean, etorkizunera begira tresna erabilgarria izan daitekeen arakatzeko. Mota honetako galderei modu positiboan erantzun diete irakasle hasiberriek beti, bideoaren eta praktika gogoetatsuaren baliagarritasuna indartuz. Irakasle-bideratzaile guztiek egiten duten galdera da.

\subsection{Laburbiltzea eta etorkizuna proiektatzea}

Adibidea 9.

Irakasle-bideratzailea 2 eta irakasle hasiberri baten arteko elkarrizketa zatia

Irakasle-bideratzailea 2: Igual bukatzeko galdera bat in nahiko nizuke. Nola ikusi dezu zure burua? Zer mantenduko zenuke? Eta zer aldatuko zenuke?

Irakasle hasiberria 2: zer mantendu? Geo ikusi nun gela zeola dena desastre ta bueno jun aurretik denen artian jasoko deu gela etxeri nitun denak berriro ta bueno denak berriro exeri? Ta bai jaso ta banan banan denei utzi nien ateatzen.

Estrategia honek irakasle hasiberrien ibilbidean laguntzea du helburu. Autokonfrontazioan esandakoei berrekin eta etorkizunera begira lanen proiekzioa egiteko lagungarria da. Kategoria hau askotan Gradu Bukaerako Lanarekin lotuta agertzen da oro har. Izan ere, Gradu Bukaerako Lana practicumean atzemandako prestakuntza behar batean oinarritzen da, eta askotan autokonfrontazioa izan ohi da behar hori azaleratzeko toki pribilegiatua. Lan honen emaitzetan ikusi dugu laburbiltzea dela irakasle-bideratzaile gehienek erabiltzen duten estrategia.

\section{EZTABAIDA}

Bederatzi kategoriaren bidez ezaugarritu dugu irakasle-prestatzaileen jarduna autokonfrontazio elkarrizketetan. Maiztasun eta distribuzio ezberdinarekin agertzen dira kategoriak dira hauek. Analisiak erakusten du zehaztapenak eskatzea eta kontrobertsia sortzea direla irakasle-prestatzaileek gehien erabiltzen dituzten kategoriak eta irakasle hasiberriei sakonago hausnartzen, praktikaren zenbait alderdi problematizatzen eta sofistikazio gehiagoz jarduten laguntzen dieten kategoriatzat har ditzakegu. Badaude ibilbidez ibilbide aipagarriak diren aldeak ere; teoriarekin loturak egitea eta babes emozionala ematea. Hala, Heziketa Fisikoa ibilbidean bereziki nabarmena da teoriarekin loturak egitea kategoriaren erabilera. Atzerriko 
Hizkuntza ibilbidean, berriz, babes emozionala ematea da gehien erabiltzen den kategoria. Kasu honetan, autokonfrontazioak etorkizuneko irakasleen hirugarren hizkuntzan egiten dira eta horrek ere izan lezake zerikusia, autokonfrontazioak eskatzen duen barne ahotsa (Friedrich, 2001) azaleratzea zailagoa baita.

Beste ikerlan batzuen ildotik (Azpeitia, Alonso \& Garro, 2013; Plazaola eta beste, 2015) bi irakasle-bideratzaile mota aurkitu ditugu: irakasleak eta irakasle-ikertzaileak. Adibidez, irakasle-ikertzaileek nabarmenki erabili dituzte hiru kategoria: kontsigna ematea, zehaztapenak eskatzea eta kontrobertsia sortzea. Kontsigna emateko modua ere desberdina da bost kasuetan eta arestian azaldu dugun bezala, nabarmentzekoa da autokonfrontazioaz eta jardueraren analisiaz ikerketa egin duten bi irakasleek oso formula antzekoa erabiltzen dutela eta beste hirurek, aldiz, askoz azkarrago eta askoz modu orokorragoan hasten dutela autokonfrontazio elkarrizketa - ebidentziarik dagoenean-. Horrek esan nahi du, gure ustez, autokonfrontazioa gidatuko duten irakasle-bideratzaileekin prestakuntza egitea interesgarria izan daitekeela. Era berean eta Beauchamp-ekin (2015) bat eginez, azpimarratu nahi dugu prestakuntza-eredua partekatua izan behar dela irakasle-bideratzaileen artean; eta ondorioz, hausnarketa-prozesua konfrontazio gurutzatuen bidez indartzea proposatzen dugu (Clot \& Faïta, 2000).

Irakasleen prestakuntzako azken formakuntza-orientabideetan jakintza profesionala jarri da erdigunean, egoera konkretuetan «egiten jakitea». Horrek dakar jarduera profesionala unibertsitatean ikasitako jakintza teorikoaren aplikaziotik harago ikustea. Jakintza hori, hala ere, inplizitua, iluna eta tazitua da gehienetan, eta bideratzaileak rol esanguratsua du jakintza hori azaleratu eta horren bidez lanbidearen inguruko jakintza eraikitzeko. Nahiz eta analisi sakonagoa behar dugun, bideo grabazioetan oinarritutako irakasleen formakuntza hobeto ulertzen hasiak gara, ikusi dugunez jarrera ebaluatzailea saihestu behar da eta deskribatzaile-aztertzaileak nagusi izan behar du (Borer \& Muller, 2016; van Es eta beste, 2014), etorkizuneko irakasleei lagundu behar zaie, aurrez prestaturiko diskurtsotik harago, irudien aurrean elkarrizketa bidez jarduera ulertzen eta horietatik abiatuz proposamen berriak eraikitzen. Jardueraren behaketa hutsa gainditzeak, azaleko itxuratik haragoko berbaldi bat irekitzeak, palanka bat dakar lan egoeren konplexutasunean murgiltzeko eta berau kontuan hartzeko. Eta horretarako irakasle-bideratzaileen lana funtsezkoa da.

Lan honen bidez, autokonfrontazio elkarrizketetan irakasle-prestatzaileen egiteko moduak hobeto ulertu ditugu bai eta, etorkizunerako hainbat aztergai finkatu ere. Auto-konfrontazioen bideo grabazioak eginez, irakasle-bideratzaileen rola hobeto ulertzeko beharra sumatu dugu; irakasle-bideratzailearen eta irakasle hasiberriaren elkarrekintza sakonago aztertu behar dugu; etorkizuneko irakasleei hausnarketa sakonago bat egiteko aukera ematen dieten galdera motak identifikatzeko beharra ikusi dugu; laginaren transkripzio gehiago aztertu eta lagina zabaltzeko beharra identifikatu dugu. 


\section{ERREFERENTZIAK}

Alsina, A. (2013). Un modelo realista para el desarrollo profesional en la formación inicial de maestros de educación infantil. Revista Electrónica Interuniversitaria de Formación delProfesorado, 16(2), 27-37. Hemen: http://dx.doi. org/10.6018/reifop.16.2.180761

Alonso, I., Azpeitia, A. Iriondo, I. \& Zulaika, T. (2017). Autoconfrontación a la propia actividad de enseñanza. Formación e investigación de la formación. Revista Electrónica Interuniversitaria de Formación del Profesorado, 20(2), 169-182.

Azpeitia, A., Alonso, I. \& Garro, E. (2013). Profesionalizazio-bidea eraikitzen. Irakasle hasiberri baten autokonfrontazio-elkarrizketaren azterketa. Ikastaria, 19, 171-196.

Beauchamp, C. (2015). Reflection in teacher education: issues emerging from a review of current literature, Reflective Practice: International and Multidisciplinary Perspectives, 16:1, 123-141.

Bikuña, A., Sagasta, P. \& Ipiña, N. (2017). Teacher educators confronting their own practice: promoting an inquiry stance in English student teachers. European Teacher Education Network Anual Conference, «Building bridges», Gothenburg, Apirilak 20-22 .

Bogdan, R.C. \& Biklen, S.K. (1992). Qualitative research for education: An introduction to theory and methods (2nd ed). Boston, MA:Allyn and Bakon.

Borer, L. \& Muller, A. (2016) L'enquete collaborative comme démarche de transformation de l'activité d'enseignement de la formation initiale o la formation continuée. Apprendre à enseigner, 193-207.

Bronckart, J.P, Bulea, E., Fillietaz, L., Fristalon, I., Plazaola Giger, I. \& Revaz, F. (2004). Agir et discours en situation de travail. Cahiers de la section des sciences de l'éducation, 103.

Burrows, J. (2008) Trainee Perceptions of observation. Huddersfield: Huddersfield Consortium.

Clot, Y. (1999). La fonction psychologique du travail. PUF: Paris.

Clot, Y.\& Faïta, D. (2000). Genres et styles en analyse du travail. Concepts et méthodes. Travailler, 4, 7-42.

Dewey, J. (1993). How we think: a restatement of the relation of reflective thinking to the educative process. Boston: D.C.Heath.

Dolz, J. \& Leutenegger, F. (2015). L'analyse des pratiques: une démarche fondamentale dans la formation des enseignants?. Formation et pratiques d'enseignement en questions, 18, 7-16.

Dörnyei, Z. (2001). Teaching and researching motivation. Harlow: Pearson Education Limited.

Durand, M. (2008). Un programme de recherche technologique en formation des adultes. Education \& Didactique, 2, 69-93.

Friedrich, J. (2001). La discussion du langage intérieur par L.S. Vygotskij, Langue Française, 57-71.

Gaudin, C. \& Chaliès, S. (2012). L'utilisation de la vidéo dans la formation professionnelle des enseignants novices : revue de littérature et zones potentielles d'étude. Revue Française de Pédagogie, 178, 115-130. 
Gaudin, C. \& Flandin, S. (2014). La vidéoformation dans tous ses états : Quelles options théoriques ? Quels scénarios ? Pour quels effets ? Chaire UNESCO «Former les enseignants au XXIe siècle» Conférence de consensus -201401-23-.

Gelfuso, A. \& Dennis, D.V. (2014). Getting reflection off the page: The challenges of developing support structures for pre-service teacher reflection. Teaching and Teacher Educaction, 38, 1-11.

Grant, C. \& Zeichner, K. (1984). On becoming a reflective teacher. Hemen: C.Grant (ed). Preparing for reflective teaching. Boston: Allyn \& Bacon.

Hatton, N. \& Smith, D. (1995). Reflection in teacher education: Towards definition and implementation. Teaching and Teacher Education, 11, 33-49.

Ipiña, N., Bikuña, A. \& Sagasta, P. (2018). Analysing the role of the facilitator in video playback in teacher education, European Teacher Education Network Anual Conference, «Diversity as a resource», Rotterdam, Martxoak 22-24.

Korthagen, F.A.J., Kessels, J., Koster, B., Lagerwerf, B. \& Wubbels, T. (2001). Linking practice and theory. N.J.: Lawrence Erlbaum Associates.

Mauri, T., Clará, M., Colomina, R. \& Onrubia, J. (2017). Patterns of interaction in the processes of joint reflection by student teachers. Journal of Education for Teaching, 43 (4), 427-443.

Newby, P. (2010). Research methods for education, Harlow: Pearson Education Research.

Ozaeta, A. (2013) Hizkuntza irakasleen prestakuntzarako eta prestakuntzaren ikerketarako proposamen bat, Ikastaria, 19, 69-95.

Peake, G. (2006). Observation of the Practice of Teaching. Huddersfield: Huddersfield Consortium.

Perez Gómez, A. (2010). Nuevas exigencias y escenarios para la profesión docente en la era de la información y de la incertidumbre. REIFOP, 64, 17-36.

Plazaola Giger, I. \& Ozaeta Elorza, A. (2014). Les formes de la parole dans l'entretien formatif d'auto-confrontation. Activités, 11(2), 112-128. http:// www.activites.org/v11n2

Plazaola, I.; Elosegi, K.; Ruiz Bikandi, U.; Arregi, A. \& Badiola, N. (2013). Irakasle hasiberriaren esperientzia. Ikastaria, 19, 139-169.

Plazaola, I. \& HIPRESTeko taldekideak (2015). Análisis de las actividades típicas de la enseñanza de las lenguas. Un proyecto científico de conocimiento y de formación del profesorado. Presentado en VII Seminario Investigación en el aula. Mondragon Unibertsitatea. Urtarrilak 22.

Pozo, M.T. \& García, B. (2006). El portafolio del alumnado. Una investigaciónacción en el aula universitaria. Revista de Educación, 341, 737-756.

Ria, L., Serres, G. \& Leblanc, S. (2009). De l'observation vidéo à l'observation in situ de trabail enseignant en milieu difficile: étude des effets sur des professeurs stagiaires. Revue Suisse des sciences de l'éducation, 31 (3), 105-120.

Russell, T. (2005). Can reflective practice be taught? Reflective practice: International and Multidisciplinary Perspective, 6(2), 199-204.

Schön, D. (1987). Educating the reflective practicioner. Towards a new design for teaching and learning in the professions. San Francisco: Jossey Bass.

Tardif, M., Borges, C. \& Malo, A. (2012). Le virage réflexif en éducation: où en sommes-nous 30 ans après Schön? Bruxelles, Belgique : De Boeck. 
Thereau, J. (1992). Le cours d'action: analyse sémio-logique: essai d'une anthropologie cognitive située. Editions Peter Lang: Berna.

Theureau, J. \& Jeffroy, F. (1994). Ergonomie des situations informatisées, Toulouse, Octares.

Tripp, T. \& Rich, P. (2012). Using video to analyze one's own teaching. British Journal of Educational Technology, 43 (4), 678-704.

van Es, E.A., Tunney, J., Goldsmith, L.T. \& Seago, N. (2014). A framework for the facilitation of teachers' analysis of video. Journal of Teacher Education, 64(5), 340-356.

Ward, J.R. \& McCotter, S.S. (2004). Reflection as a visible outcome for preservice teachers. Teaching and Teacher Education, 20, 243-257

Zabalza, M.A. (2004). Diarios de clase. Un instrumento de investigación y desarrollo profesional. Madrid: Narcea. 